\title{
Assessing the Ecosystem Services of Various Types of Urban Green Spaces Based on i-Tree Eco
}

\author{
Peihao Song ${ }^{1,2}$, Gunwoo Kim ${ }^{3, *}$, Audrey Mayer ${ }^{2}$, Ruizhen $\mathrm{He}^{1}$ and Guohang Tian ${ }^{1, *}$ \\ 1 Department of Landscape Architecture, College of Forestry, Henan Agricultural University, \\ Zhengzhou 450002, China; peihaos@mtu.edu (P.S.); hrzzjd@126.com (R.H.) \\ 2 College of Forest Resources and Environmental Science, Michigan Technological University, \\ Houghton 49931, MI, USA; almayer@mtu.edu \\ 3 Graduate School of Urban Studies, Hanyang University, Seoul 04763, Republic of Korea \\ * Correspondence: gwkim1@hanyang.ac.kr (G.K.); tgh@henau.edu.cn (G.T.); \\ Tel.: +82-2-2220-0274 (G.K.); +86-0371-6355-8098 (G.T.)
}

Received: 3 February 2020; Accepted: 20 February 2020; Published: 21 February 2020

\begin{abstract}
Urban green spaces play a crucial role in maintaining urban ecosystem sustainability by providing numerous ecosystem services. How to quantify and evaluate the ecological benefits and services of urban green spaces remains a hot topic currently, while the evaluation is barely applied or implemented in urban design and planning. In this study, super-high-resolution aerial images were used to acquire the spatial distribution of urban green spaces; a modified pre-stratified random sampling method was applied to obtain the vegetation information of the four types of urban green spaces in Luohe, a common plain city in China; and i-Tree Eco model was further used to assess the vegetation structure and various ecosystem services including air quality improvement, rainfall interception, carbon storage, and sequestration provided by four types of urban green spaces. The modeling results reveal that there were about 1,006,251 trees in this area. In 2013, all the trees in these green spaces could store about 54,329 $\mathrm{t}$ of carbon, sequester about $4973 \mathrm{t}$ of gross carbon, remove $92 \mathrm{t}$ of air pollutants, and avoid $122,637 \mathrm{~m}^{3}$ of runoff. The study illustrates an innovative method to reveal different types of urban green spaces with distinct ecosystem service productivity capacity to better understand their various roles in regulating the urban environment. The results could be used to assist urban planners and policymakers to optimize urban green space structure and composition to maximize ecosystem services provision.
\end{abstract}

Keywords: urban green space; ecosystem services; i-Tree Eco; vegetation structure; Luohe

\section{Introduction}

Urban green space, as an inseparable element of urban ecosystems, provides critical ecosystem services [1,2] for human wellbeing, like air quality improvement [3,4] through pollution removal and noise reduction, water and soil conservation [5], microclimate regulation [6,7], urban heat island (UHI) mitigation [8], biodiversity conservation [9,10], etc. Meanwhile, urban green spaces also bring economic and social benefits [11,12], for instance, energy saving, promoting community integration [13], and outdoor recreation. Their potential contribution to citizens is also being increasingly acknowledged.

Urban ecosystem services of green spaces have been identified, quantified, and assessed to inform taxpayers and support urban planning and decision-making processes [14-20]. However, urban ecosystem services are rarely involved in actual urban design and planning because of the lack of sufficient basic research about urban green space ecosystem services [21,22]. Urban planners and policymakers often lack knowledge of the benchmarks for ecosystem productivity when setting specific planning goals or expectations [16,23]. Furthermore, many studies focus on the different eco-functions 
of various vegetation communities within the urban area [24-29], while there are few studies that analyze variations in types and functions of urban green spaces at finer scales $[1,22,30]$. Urban green spaces are divided into several types, reflecting the different needs that these spaces meet, which could further affect the different ecosystem services provision. The capacity of various green spaces ecosystem services provision is context-specific and different depending on their type and size [31,32]. Various types of urban green spaces such as public parks, road belt green space, wetland, and private gardens are extremely heterogeneous with different vegetation communities and diversities reflecting diverse social needs and personal preferences that further influence eco-function value provision [33].

In China, spatially heterogeneous urban green spaces are classified into four main types, which are public parks, protective green spaces, square green spaces, and attached green spaces by individual location and function across urban area based on Standard for Classification of Urban Green Space (CJJ/T85-2017), which was released by Ministry of Housing and Urban-Rural Development of P.R.C. in 2017. Different social needs and ecological values that are driven by landowners' preferences and function-oriented design bring various types of urban green spaces [34]. Diverse vegetation preferences and differing management and maintenance practices reflect human-oriented design within different types of urban green spaces $[35,36]$.

Urban green spaces regulate regional microclimate via shading, evapotranspiration, boosting air movements, and increasing heat exchange, which mitigates urban heat island (UHI) effects at a city scale [37-39]. Furthermore, vegetation in green spaces can not only intercept rainfall and reduce rainfall runoff, but also bring more rainfall infiltration, which decreases the frequency of urban floods and stormwater treatment costs and damages [40]. These ecological benefits are based on the composition and structure of the urban forest, which is crucial for improving and regulating the urban environment [25]. Exposing how different types of urban green spaces impact ecosystem service performance could help policymakers and urban planners to optimize green space planning and maximize ecosystem services provision. However, there are many studies focusing on how vegetation types like trees, shrubs and herbaceous, or vegetation communities perform in ecosystem services provision [28,41-46]. There are comparatively few studies concerning different types of urban green space ecosystem service provision and baseline information is not available on the vegetation structure, ecosystem benefits, and value of various types of urban green spaces in Luohe. An assessment of the city's urban green spaces is also needed to make the policymakers, urban planners, city managers, and the general public aware of the ecosystem services that their green spaces provide to better preserve, manage, and maintain the existing urban green spaces in Luohe. In this paper, a spatial distribution database of the four types of urban green spaces was acquired by high-resolution aerial images interpretation and pre-stratified random plots were created to collect vegetation information of the four types of urban green spaces. An i-Tree Eco model was then used to assess their vegetation composition and structure and ecosystem services. Using these methods, the paper explores how different types of urban green spaces perform in ecosystem services provision in Luohe. The baseline information could be used for optimized management decision-making and planning, developing suitable policies, and setting a maintenance plan for Luohe. Better-treated urban green spaces in this area could contribute to air quality improvement and a better living environment for the general public. The selected ecosystem services in this study were carbon storage and sequestration, air pollution removal, and runoff avoidance. Because all the sample plots were created within the green space, and there was less building information in these sample plots, energy saving was not discussed in this study. The objective of this study is to reveal the difference in vegetation structure of the four types of urban green spaces, to highlight how the various types of urban green spaces perform in ecosystem service provisioning in Luohe, and to demonstrate how to increase and maximize the ecosystem services provisioning in the future. 


\section{Materials and Methods}

\subsection{Study Area}

Luohe city was selected as the research area due to its large number and considerable diversity of urban green spaces. Luohe city is a common medium-size plain city located in south-central Henan Province, China (Latitude $33^{\circ} 34^{\prime} 55.36^{\prime \prime} \mathrm{N}$, Longitude $114^{\circ} 0^{\prime} 38.70^{\prime \prime}$ E, Figure 1). Luohe is situated in the Cfa climate zone (Köppen Climate Classification System), and its elevation is 56 to $59 \mathrm{~m}$ above sea level. Luohe consists of three districts, Yancheng, Yuanhui, and Shaoling, with a combined population of 720,000, and a total of 8000 ha of land (2018 Henan Statistical Yearbook). The urban green space ratio reaches $34 \%$ and the per capita public green space is 11.8 square meters (2018 Government Work Report of Luohe). Two seasonal (January and June, 2016) super high-resolution (9 cm) Unmanned Aerial Vehicle (UAV) images were available, which could be interpreted to achieve the amounts and spatial distribution of urban green spaces in Luohe city.
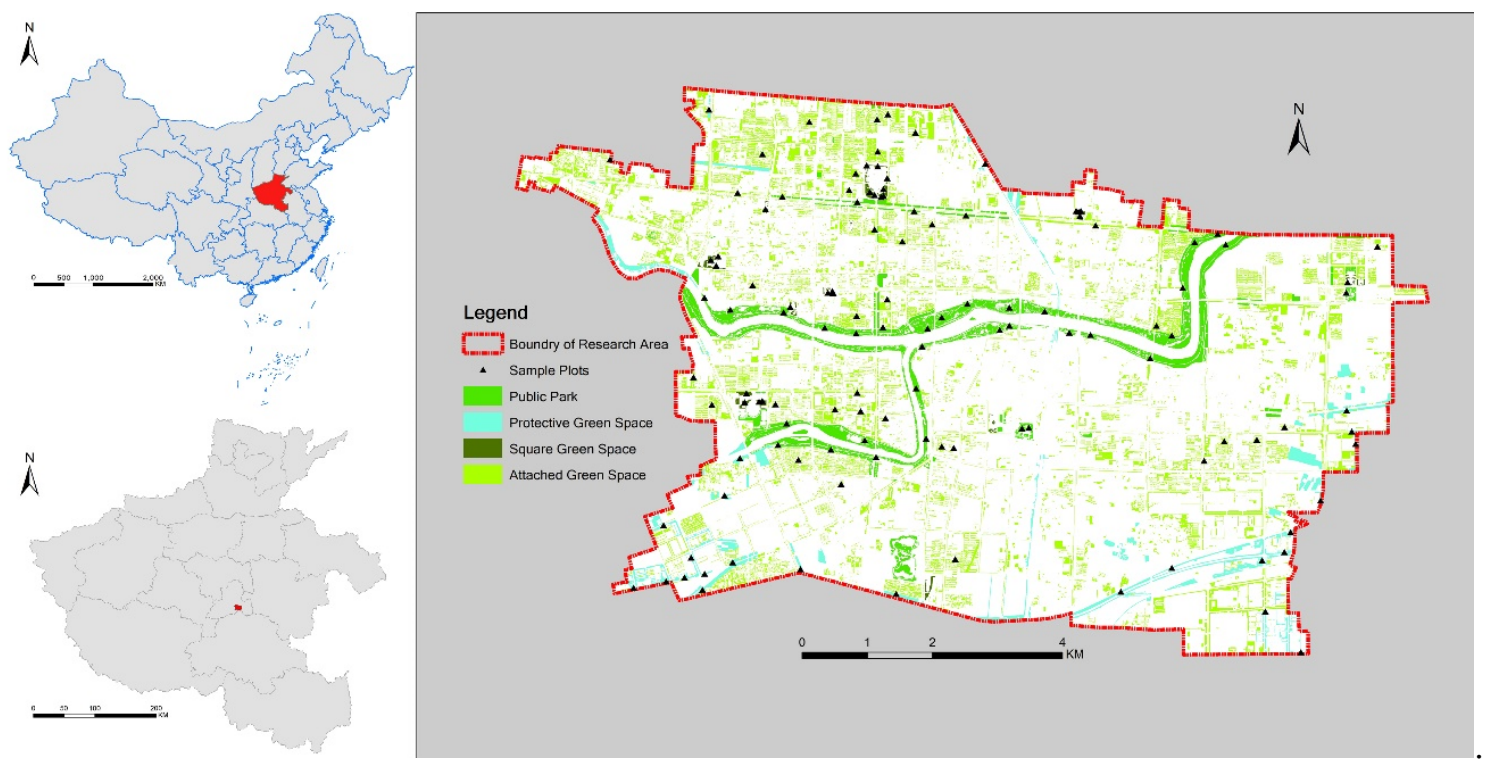

Figure 1. Location of Henan Province and Luohe City in central China (left); Pre-stratified sample plots and spatial distribution of the four types of urban green spaces in Luohe (right).

\subsection{Sample Plots Establishment}

The three methods of sample plot establishment using the i-Tree model are the layering method, random method, and grid method [25]. According to the i-Tree Eco v6 protocol, we could pre-stratify or post-stratify the study area into smaller parts to better understand the differences across the various strata [47]. An innovative application of i-Tree Eco was utilized in this study by creating sample plots based on a pre-stratification scheme within the urban green spaces, which brought more valid sample plots and vegetation information than normal random sample creation across the whole study area. Four types of urban green spaces in Luohe were interpreted, classified, and delineated manually [48] based on two-seasonal UAV images by combining with a Present Land Use Map of Luohe, which was used to obtain a spatially explicit representation of the four types of urban green spaces (Figure 2). Based on Random Plots Workbook from i-Tree Eco User's Manual (2018), ArcGIS software with the Spatial Analysis tools was utilized to create stratified random sample plots within the four types of urban green spaces. A total of 120 circular $404.7 \mathrm{~m}^{2}$ plots (Table 1) were created with public parks (35 plots), protective green spaces (25 plots), attached green spaces (35 plots), and square green spaces (25 plots). Each plot had an area of $404.7 \mathrm{~m}^{2}$ as recommended by Nowak et al. [49]. The plots were proportionally assigned to the four types of urban green spaces according to individual total area and 
complexity. Individual plot maps, at a scale of 1:500, with clear boundaries, were created from the UAV images and printed to assist with the field survey.

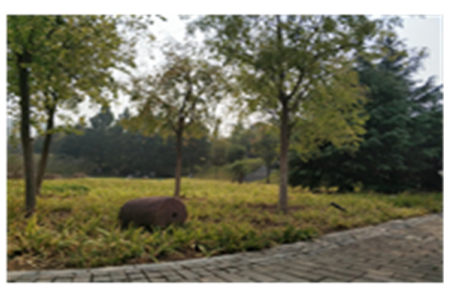

(a)

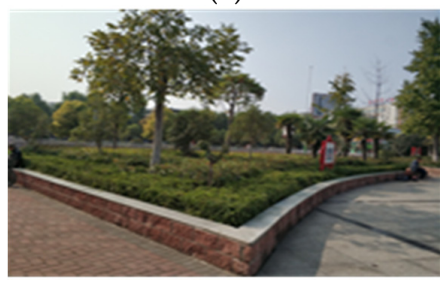

(c)

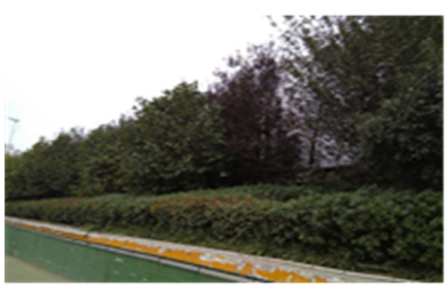

(b)

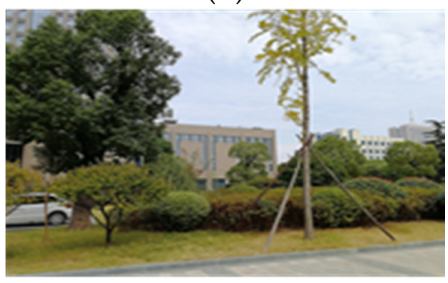

(d)

Figure 2. Samples of urban green spaces in Luohe, (a) Public park; (b) Protective green space; (c) Square green space; (d) Attached green space.

Table 1. Area and number of created sample plots of the four types of urban green spaces in Luohe.

\begin{tabular}{|c|c|c|c|}
\hline $\begin{array}{l}\text { Type of Urban } \\
\text { Green Space }\end{array}$ & Area (ha) & $\begin{array}{l}\text { Number of } \\
\text { Sample Plots }\end{array}$ & $\begin{array}{l}\text { Definition of Typology of Urban Green Space } \\
\text { (Revised from CJJ/T85-2017) }\end{array}$ \\
\hline Public Park & 765 & 35 & $\begin{array}{l}\text { Code: G1, publicly accessible, including all kinds of } \\
\text { parks, like comprehensive parks, community parks, } \\
\text { theme parks, botanic gardens, belt parks, etc. }\end{array}$ \\
\hline $\begin{array}{c}\text { Protective Green } \\
\text { Space }\end{array}$ & 390 & 25 & $\begin{array}{l}\text { Code: G2, not suitable access, used for ecological } \\
\text { isolation, security, protection, including highway and } \\
\text { railway belt protective green space, high tension } \\
\text { corridor protective green space, etc. }\end{array}$ \\
\hline Square Green Space & 41 & 25 & $\begin{array}{l}\text { Code: G3, publicly accessible open space, used for } \\
\text { recreation, memorial, rally, emergency and } \\
\text { disaster-prevention, tree coverage above } 35 \% \text {. }\end{array}$ \\
\hline $\begin{array}{c}\text { Attached Green } \\
\text { Space }\end{array}$ & 2123 & 35 & $\begin{array}{l}\text { Code: } X G \text {, attached to all kinds of land use, including } \\
\text { residential, public management and service, } \\
\text { commercial, industrial, logistics and warehousing, } \\
\text { road and transportation, public facility, etc. }\end{array}$ \\
\hline Study Area & 3319 & 120 & 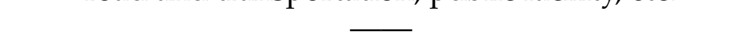 \\
\hline
\end{tabular}

\subsection{Data Collection and Analysis}

Following the i-Tree Eco data collection protocol, field data such as plot information, groundcover information, vegetation information were collected via field survey during the leaf-on season (May to August in 2018) to identify and measure the trees properly. To be more specific, plot information includes tree and shrub cover percentage, plantable space area and ground cover types under canopy; shrub information was collected including species, average height, percent area, percent of mass missing, etc.; tree information including tree species, total height, diameter at breast height $(\mathrm{DBH}, 1.37 \mathrm{~m}$ from the base), canopy missing percentage, crown size, crown health condition, crown light exposure, etc. A total of 111 plots with 35 public park plots, 23 protective green space plots, 33 attached green space plots, and 23 square green space plots were investigated, while 9 plots were unachievable and 5 plots were misclassified. All the field data were imported from Excel files to Access files in the i-Tree Eco model by a hacking method to further analyze and assess vegetation structures of urban green spaces and associated ecosystem services. 


\section{4. i-Tree Eco V6 Modeling and Analysis}

$\mathrm{i}$-Tree model is a software suite developed by the USDA Forest Services to help managers and researchers quantify urban forest structure and ecological functions (www.itreetools.org). i-Tree Eco (formerly called UFORE, Urban Forest Effects Model) is designed to utilize standardized field data from sample plots or complete inventories, together with local hourly air pollution and meteorological data to analyze a detailed characterization of urban forest structure and quantify numerous ecological services for cities [25]. The i-Tree model has been widely used in case studies across the world to assess total ecosystem services for whole research areas without stratification or to compare one single stratum within a research area [50-54]. This research represents an innovative application of i-Tree Eco, using pre-stratified random sample plots created within the four types of urban green spaces to reveal the various characterizations of diverse types of urban green spaces in Luohe. Pollution data including hourly concentrations of $\mathrm{NO}_{2}, \mathrm{SO}_{2}, \mathrm{CO}, \mathrm{O}_{3}, \mathrm{PM}_{10}$, and $\mathrm{PM}_{2.5}$ were obtained from the online national database, hosted by the Ministry of Ecology and Environment of P.R.C. (www.mee.gov.cn). Local hourly meteorological data were acquired from Luohe Meteorological Service. Air pollution and weather data from 2013 were used in this study.

\section{Results}

In this study, based on the leaf-off season high-resolution UAV images, only the plantable and pervious area of urban green spaces were identified, interpreted, and delineated manually, while using the interpretation procedure, appurtenances in the green spaces like outbuildings, trails, paved surfaces, etc. were excluded, so the areas of individual types of urban green spaces discussed in this study were smaller than actual area.

\subsection{Spatial Distribution of the Four Types of Urban Green Spaces Across the City}

Green space coverage in Luohe covered about $38 \%$ of the urban area. Considering the four main types of urban green spaces, attached green spaces (2123 ha) was the highest coverage type of green spaces in the city, followed by public parks $(765 \mathrm{ha})$, protective green spaces (390 ha), and square green spaces (41 ha).

By using the Sha and Li River as the natural boundary of the city, the city area was divided into three parts, the north part, the south part, and the west part. The north part obviously had more green spaces than the south part. The south part, as the old district, had few green spaces due to historical factors and land conflicts. Since 2000, the north part as the new district began to be planned and developed, with an increasing awareness of a better living environment, lots of green spaces were planned initially and implemented to meet increasing needs. The west part was developed with modern sustainable development strategies from 2010, relying on natural resources, lots of street parks, and wetland parks were established until now. There was a notable difference in the individual numbers of the four types of green spaces, and the distribution of the four types of urban green spaces was not even across various land uses in Luohe.

Attached green spaces were not only the largest area type of green space but also the most widely extended all over the city. The public parks were mainly located along Sha and Li River, but plenty of areas lacked public parks or even small-size street-corner parks. Protective green space areas ranked third, and mainly could be found along the highways, canals, and near plants. Square green space areas were the least numerous type, as there were only six public squares and all the plantable coverage was less than $35 \%$.

\subsection{Structural Variables of the Four Types of Urban Green Spaces}

The model results show considerable variation among the four types of green spaces in terms of structural variables (Table 2). There were approximately 1,006,251 trees within whole green spaces in Luohe. Attached green spaces had the largest number of trees, accounting for more than $56.4 \%$ of all 
trees in Luohe, followed by public parks (27.0\%), protective green spaces $(15.3 \%)$, and square green spaces $(1.4 \%)$. The highest average tree density was found in protective green spaces ( 974 trees/ha), followed by public parks, and square green spaces. Attached green spaces had the least tree density with 660.2 trees/ha.

Table 2. Vegetation characterization and structure of the four types of urban green spaces in Luohe.

\begin{tabular}{|c|c|c|c|c|c|c|c|c|c|}
\hline Stratum & $\begin{array}{c}\text { Acquired } \\
\text { Sample } \\
\text { Plots }\end{array}$ & $\begin{array}{l}\text { Number } \\
\text { of Trees }\end{array}$ & $\begin{array}{c}\text { Percent of } \\
\text { Population }\end{array}$ & $\begin{array}{l}\text { Tree Density } \\
\text { (Number/ha) }\end{array}$ & $\begin{array}{l}\text { Tree and Shrub } \\
\text { Leaf Area } \\
\text { Density }\left(\mathrm{m}^{2} / \mathrm{ha}\right)\end{array}$ & $\begin{array}{c}\text { Tree } \\
\text { Species } \\
\text { Richness }\end{array}$ & SPP $^{1}$ & $\begin{array}{l}\text { Simpson's } \\
\text { Diversity } \\
\text { Index }\end{array}$ & $\begin{array}{c}\text { Percent of } \\
\text { Native } \\
\text { Species }\end{array}$ \\
\hline Public Park & 35 & 271,662 & $27.0 \%$ & 878 & $102,922.1$ & 42 & 73 & 20.2 & 90.2 \\
\hline Square Green Space & 22 & 13,631 & $1.4 \%$ & 822 & $95,315.6$ & 30 & 83 & 16.4 & 93.5 \\
\hline Attached Green Space & 32 & 567,209 & $56.4 \%$ & 660 & $82,018.7$ & 49 & 94 & 19.3 & 93.0 \\
\hline Study Area & 111 & $1,006,251$ & $100.0 \%$ & 749 & $90,544.7$ & 69 & 38 & 19.4 & 92.4 \\
\hline
\end{tabular}

${ }^{1}$ SPP: the number of species found in the sampled area per hectare.

In terms of diversity indices, attached green spaces had the highest richness with 93.5 species/ha, followed by protective green spaces and square green spaces with 88.8 and 83.3 species/ha, respectively, while public parks had the lowest richness with 73.3 species/ha. A higher Simpson's diversity index, which means greater species diversity [55], was found in public parks (20.2) and attached green spaces (19.3). Protective green spaces had the lowest Simpson's diversity index with 8.1.

Concerning the tree age distribution (Figure 3), more than $62.7 \%$ of trees had DBH $\leq 15.2 \mathrm{~cm}$ in the whole study area, which means that there are abundant young trees and, thus, a potential to contribute to urban ecosystem services provision in the coming years. Only $4.5 \%$ of trees with DBH were higher than $30.6 \mathrm{~cm}$. Results showed a similar ranking with tree density concerning tree and shrub leaf area density and leaf biomass, where protective green spaces had the highest leaf area density, followed by public parks. However, square green spaces yielded the highest leaf biomass with 12,976.5 kg/ha (Table 3), while attached green spaces had the lowest leaf biomass with $7735.6 \mathrm{~kg} / \mathrm{ha}$. It is notable that shrubs in square green spaces made significant contributions to leaf biomass, which was equal to half that of the contribution of trees.

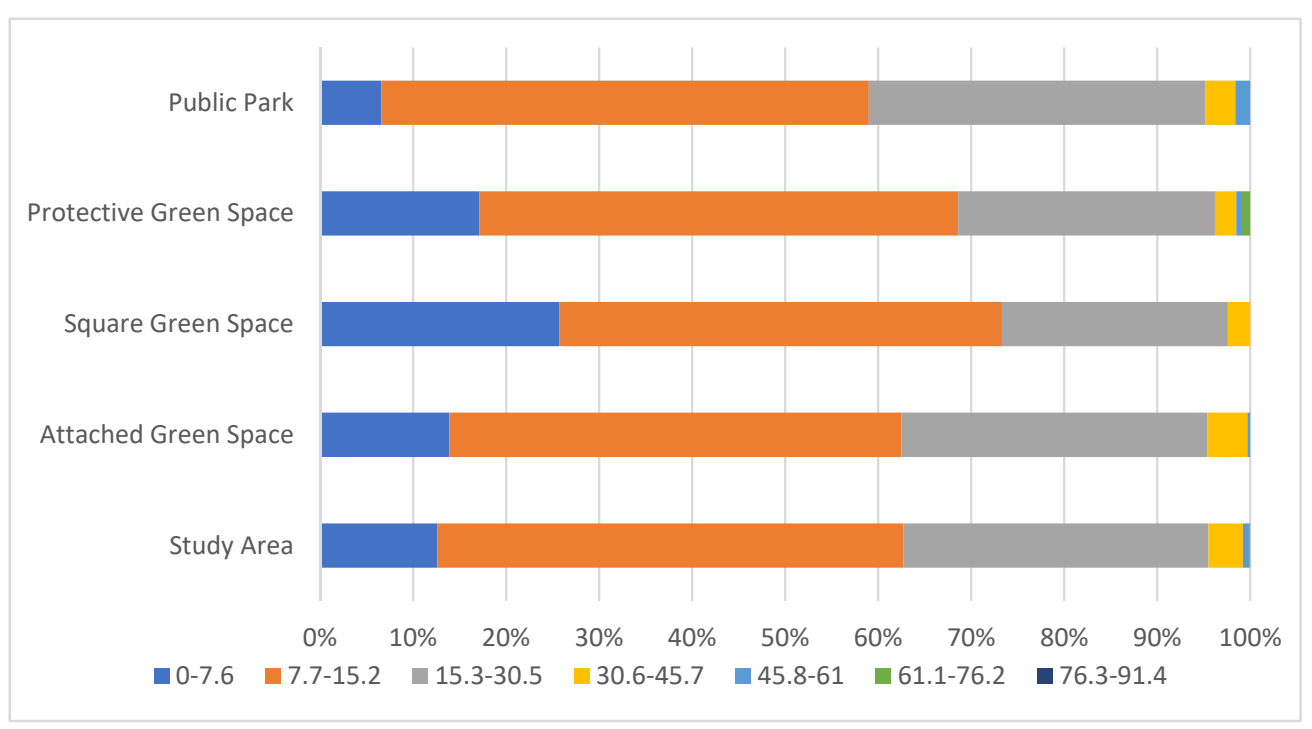

Figure 3. Tree population composition of the four types of urban green spaces in Luohe, classified by DBH groups (Unit: cm). 
Table 3. Modeling results of the four types of urban green spaces in Luohe, assessed via i-Tree Eco.

\begin{tabular}{|c|c|c|c|c|c|c|c|c|c|c|}
\hline Stratum & $\begin{array}{c}\text { Tree Leaf } \\
\text { Biomass } \\
\text { (kg/ha) }\end{array}$ & $\begin{array}{c}\text { Shrub Leaf } \\
\text { Biomass } \\
\text { (kg/ha) }\end{array}$ & $\begin{array}{l}\text { Carbon } \\
\text { Storage } \\
(\mathrm{kg} / \mathrm{yr} / \mathrm{ha})\end{array}$ & $\begin{array}{c}\mathrm{CO}_{2} \\
\text { Equivalent } \\
(\mathrm{kg} / \mathrm{yr} / \mathrm{ha})\end{array}$ & $\begin{array}{c}\text { Net Carbon } \\
\text { Sequestration } \\
\text { Density } \\
\text { (kg/yr/ha) }\end{array}$ & $\begin{array}{c}\mathrm{CO}_{2} \\
\text { Equivalent } \\
\text { (kg/yr/ha) }\end{array}$ & $\begin{array}{c}\text { Water } \\
\text { Intercepted } \\
\left(\mathrm{m}^{3} / \mathrm{yr}\right)\end{array}$ & $\begin{array}{c}\text { Avoided } \\
\text { Runoff } \\
\left(\mathrm{m}^{3} / \mathrm{yr}\right)\end{array}$ & $\begin{array}{c}\text { Interception } \\
\text { Efficiency } \\
\left(\mathrm{m}^{3} / \mathrm{yr} / \mathrm{ha}\right)\end{array}$ & $\begin{array}{c}\text { Runoff } \\
\text { Avoiding } \\
\text { Efficiency } \\
\left(\mathrm{m}^{3} / \mathrm{yr} / \mathrm{ha}\right)\end{array}$ \\
\hline Public Park & 7578.8 & 1227.9 & $57,970.0$ & $212,576.0$ & 4701.0 & $17,238.7$ & $182,765.3$ & $39,106.6$ & 238.9 & 51.1 \\
\hline Protective Green Space & 7695.2 & 1718.5 & $59,281.6$ & $217,385.5$ & 3995.3 & $14,650.7$ & $83,929.2$ & $17,958.4$ & 215.2 & 46.0 \\
\hline Square Green Space & 8768.4 & 4208.1 & $29,017.4$ & $106,406.8$ & 3281.0 & $12,031.2$ & 4695.5 & 1004.7 & 114.5 & 24.5 \\
\hline Attached Green Space & 5958.9 & 1776.7 & $30,894.3$ & $113,289.4$ & 2937.4 & $10,771.3$ & $301,755.8$ & $64,567.1$ & 142.1 & 30.4 \\
\hline Study Area & 6571.0 & 1673.4 & $40,447.5$ & $148,320.9$ & 3472.4 & $12,733.4$ & $573,145.7$ & $122,636.8$ & 172.7 & 36.9 \\
\hline
\end{tabular}




\subsection{Carbon Storage and Sequestration}

Photosynthesis, which converts inorganic matter into organic matter and releases oxygen, is one of the physiological features of trees via their tissue. During the physiological process, carbon dioxide in the air is not only reduced, but oxygen is also produced, maintaining the balance of carbon and oxygen in the air. Annual carbon sequestration efficiency showing the annual carbon absorption capacity could be calculated by i-Tree Eco, which is related to tree size, health condition, canopy coverage, and spatial distribution. All the trees of the four types of green spaces in Luohe could store approximately $54,329 \mathrm{t}$ of carbon in 2013. There were around $4973 \mathrm{t}$ of gross carbon sequestration from these green spaces annually. Different types of green spaces had various carbon sequestration capacities, while public parks had the highest net carbon sequestration efficiency with $4701 \mathrm{~kg} / \mathrm{yr} / \mathrm{ha}$, attached green spaces had the lowest one with $2937 \mathrm{~kg} / \mathrm{yr} / \mathrm{ha}$.

Carbon storage efficiency exhibits a very different ranking, where protective green spaces had the highest carbon storage efficiency with $59,281 \mathrm{~kg} / \mathrm{ha}$, followed by public parks with $57,970 \mathrm{~kg} / \mathrm{ha}$, while attached green spaces and square green spaces had the lowest carbon storage capacity with $30,894 \mathrm{~kg} / \mathrm{ha}$ and $29,017 \mathrm{~kg} / \mathrm{ha}$, respectively.

\subsection{Air Pollution Removal}

Since the 1950s, air quality issues have been a major concern worldwide [56]. Air quality is therefore not only a pressing public health issue but is also affects ecosystem health [2]. Trees in urban areas could remove air pollutants and improve air quality by absorbing harmful gas from cars or plants and intercepting particulate matter [57-60]. Trees could absorb and filter large amounts of particulate matter, nitrogen oxides, and sulfide every year [57,61]. i-Tree could quantify and estimate the total amount of various harmful substances in the air purified by trees [62]. As shown in Figure 4, about $92 \mathrm{t}$ of air pollutants $\left(\mathrm{CO}, \mathrm{NO}_{2}, \mathrm{O}_{3}, \mathrm{PM}_{2.5}, \mathrm{SO}_{2}\right)$ were removed by all the trees in 2013. Of these pollutants, there were more than $47.4 \mathrm{t}$ of $\mathrm{O}_{3}$ removed by trees accounting for $51.5 \%$ of total pollutants. Only $0.6 \mathrm{t}$ of $\mathrm{PM}_{2.5}$ was removed in 2013. A similar trend can be seen with total leaf area ranking, the highest pollutant removing capacity was found in attached green spaces with $48.4 \mathrm{t}$ in 2013 and square green spaces had the lowest capacity with $0.7 \mathrm{t}$. In terms of the efficiency of the removal of different pollutants (Figure 5), the four types of green spaces had obvious differences in the removal of various air pollutants ranging between $0.13 \mathrm{~kg} / \mathrm{ha}$ to $19.8 \mathrm{~kg} / \mathrm{ha}$. Attached green spaces could remove $19.8 \mathrm{~kg}$ per ha, while only removing $0.27 \mathrm{~kg}$ of PM2.5. Square green spaces had the lowest air pollution removal capacity from $0.13,0.65,3.9,4.1,9.2 \mathrm{~kg} / \mathrm{ha}, \mathrm{PM}_{2.5}, \mathrm{CO}, \mathrm{NO}_{2}, \mathrm{SO}_{2}, \mathrm{O}_{3}$, respectively.

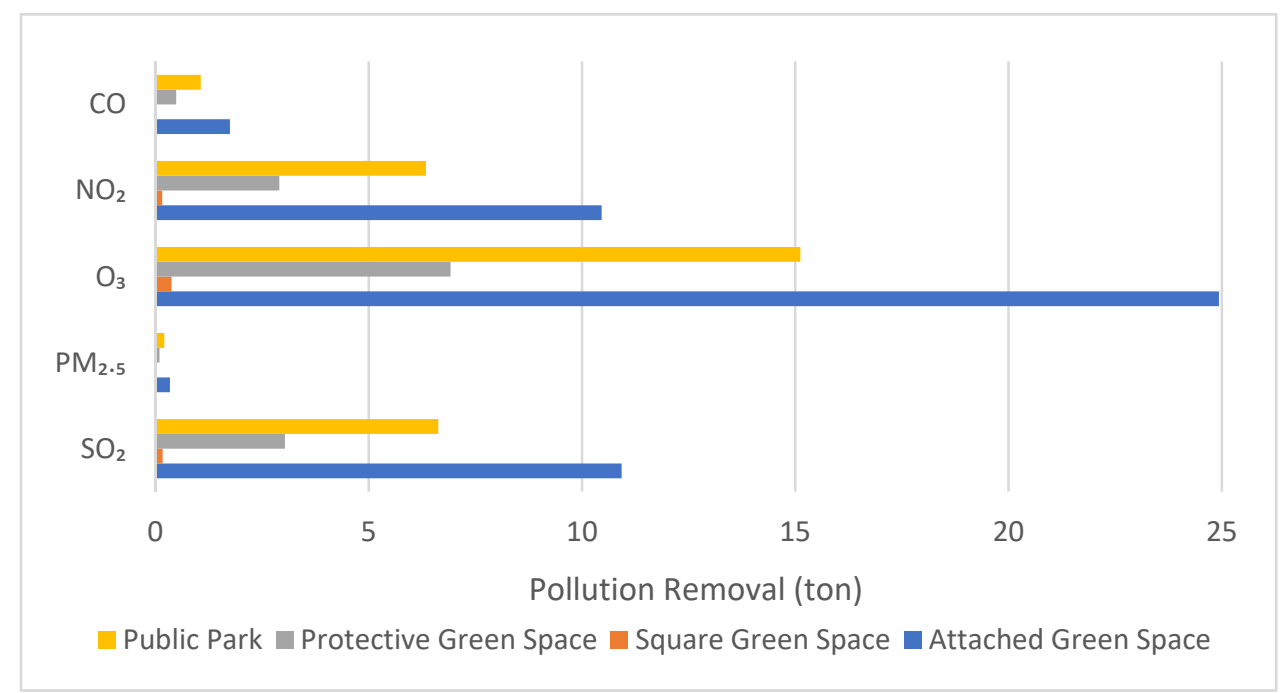

Figure 4. Air pollution $\left(\mathrm{CO}, \mathrm{NO}_{2}, \mathrm{O}_{3}, \mathrm{PM}_{2.5}, \mathrm{SO}_{2}\right)$ removal by the four types of urban green spaces in Luohe. 


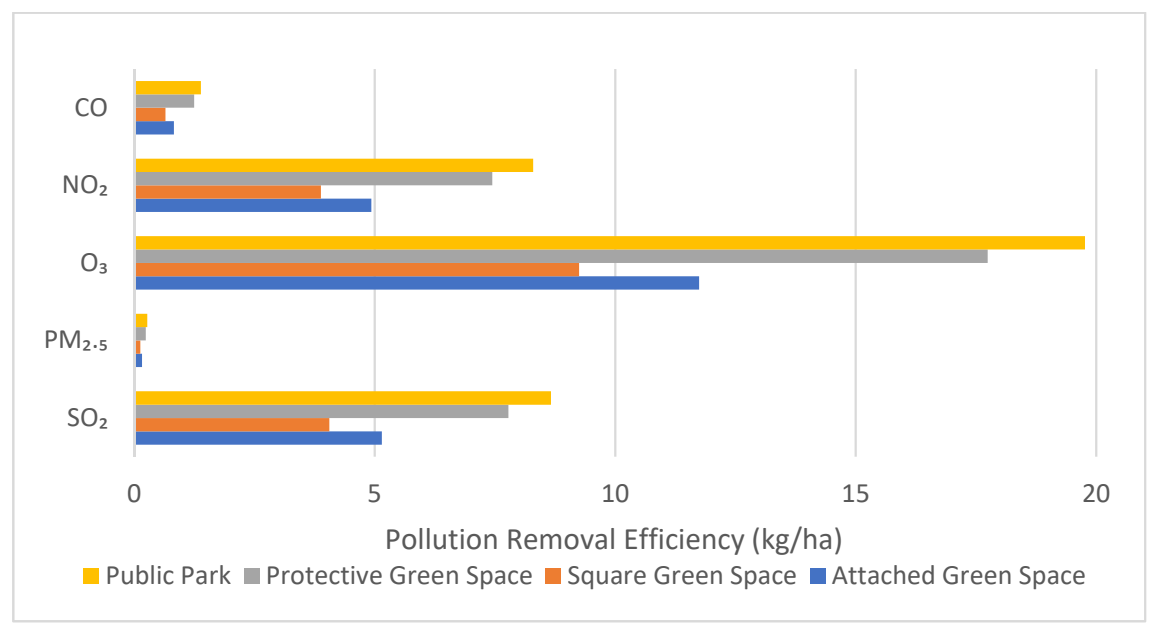

Figure 5. Yearly air pollution $\left(\mathrm{CO}, \mathrm{NO}_{2}, \mathrm{O}_{3}, \mathrm{PM}_{2.5}, \mathrm{SO}_{2}\right)$ removal efficiency of the four types of urban green spaces in Luohe.

\subsection{Runoff Reduction}

Globally, urban floods are frequent occurrences [63,64]. Floods increase the contamination of surface runoff in urban areas and lead to continuously deteriorating water quality in streams, rivers, lakes, and wetlands [65]. When it rains, some portion of precipitation is intercepted and stored by the vegetation canopy, bark, and branches, while the remainder reaches the ground. The precipitation that falls on pervious or impervious surfaces and cannot infiltrate into the soil becomes surface runoff. Furthermore, the overwhelming impervious coverage in the urban area increases the amount and density of surface runoff [66]. Many studies have shown that trees in urban areas play a crucial role in stormwater runoff reduction [67-69]. Results show that an estimated 122,636.8 $\mathrm{m}^{3}$ of avoided runoff in 2013 was due to whole green spaces. The avoided runoff ranking had a similar trend as the individual areas of each type of green space. However, the stormwater interception efficiency of different types of green spaces varied considerably, public parks had the highest efficiency with $238.9 \mathrm{~m}^{3} / \mathrm{ha} / \mathrm{yr}$, followed by protective green spaces and attached green spaces with 215.2 and $142.1 \mathrm{~m}^{3} / \mathrm{ha} / \mathrm{yr}$. Square green spaces had the lowest interception efficiency with $114.5 \mathrm{~m}^{3} / \mathrm{ha} / \mathrm{yr}$, which was less than half that of public parks. Compared to the interception efficiency, the runoff avoiding efficiency of the four types of green spaces had the same ranking and was pretty low, public parks had the highest efficiency with $51.1 \mathrm{~m}^{3} / \mathrm{ha} / \mathrm{yr}$, which means that only $21.4 \%$ of the intercepted stormwater was captured. The rest of the intercepted stormwater would evaporate into the air or become runoff. In terms of individual tree interception capacity, individual trees in public parks had the highest capacity with $0.67 \mathrm{~m}^{3} / \mathrm{yr}$, followed by 0.55 and $0.53 \mathrm{~m}^{3} / \mathrm{yr}$, for protective green spaces and attached green spaces, respectively, while square green space trees had the lowest with $0.34 \mathrm{~m}^{3} / \mathrm{yr}$.

\section{Discussion}

\subsection{Analysis and Implications From Results}

Innovative sampling approaches that create sample plots within the various types of green spaces can acquire more valuable tree information than standard i-Tree Eco sampling methods, and also better tree structure and ecosystem services estimations.

\subsubsection{Vegetation Structure of Urban Green Spaces}

Concerning vegetation structure, the urban green space is a mix of native and exotic tree species composed, while different types of green space consist of various vegetation compositions or communities that play an individual role or function. Not surprisingly, public parks and attached green spaces have higher species diversity than protective and square green spaces, as they both have 
multiple functions and the various activities' spaces are comprised of vegetation to meet all ages' needs. Protective and square green spaces have single or specific functions resulting from simple vegetation communities within these areas. A higher species diversity could minimize ecological vulnerability to natural disaster, while low species diversity has low ecosystem resilience [70]. High biodiversity not only boosts ecosystem productivity, but also provides a healthy ecosystem to support natural sustainability, which can lead to high resilience, in regard to withstanding and recovering from natural hazards [71]. More attention should be focused on improving species diversity in protective square green spaces.

\subsubsection{Ecosystem Service Provision of the Four Types of Urban Green Spaces}

The results of spatial distribution and an ecosystem service comparison of the four types of urban green spaces reveal that the ratio of the four types of green spaces is unbalanced and attached green spaces accounting for $56.4 \%$ of total trees offer the greatest ecosystem benefits. The highest carbon storage efficiency was found in protective green spaces. Protective green spaces had the highest tree density and thus have more above-ground biomass (carbon storage) than other types of green space. Public parks had higher net carbon sequestration efficiency than protective green space. By comparing the tree DBH proportion of public parks and protective green spaces, although protective green spaces have higher tree density per ha, public parks have fewer small trees $(\mathrm{DBH} \leq 7.6 \mathrm{~cm})$ and more medium trees $(15.3 \mathrm{~cm} \leq \mathrm{DBH} \leq 30.5)$ than protective green space. Meanwhile, trees in public parks are well maintained, receiving regular watering and fertilizing, and public parks have more large trees resulting in a higher leaf area density. Obviously, large trees can provide significantly more ecosystem services than small trees, while there are far more small trees in protective green spaces, which will mature and have the potential to provide more ecosystem services in the coming years, and these trees should be well treated and maintained.

The comparison of ecosystem service efficiency of the four types of urban green spaces indicates that attached green spaces had the highest capacity and public parks had the highest efficiency in providing ecosystem services for the city. Attached green spaces as the most widely distributed type of green spaces had the closest connection with citizenship. According to the Classification Standard of Urban Green Space (CJJ/T85-2017), green space located in residential areas, municipal service areas, commercial areas, industrial land, warehousing land, public facility area, and road and traffic facility areas is attached green space. Attached green spaces not only provide recreation areas for human beings but also decorate the living environment. These have the closest relationship with human life and play a key role in the maintenance of ecological balance [72]. This suggests that the role of attached green spaces in improving the urban environment and human life should be acknowledged, well maintained and protected. Although attached green spaces account for a major percentage $(64 \%)$ of the total green space area, it has the lowest tree density per ha, resulting in a low ecosystem service provision efficiency. With continuous maintenance and maturing in the future, attached green spaces have great potential to be the most effective green space type with increasing ecosystem services provision efficiency in Luohe. Square green spaces had the lowest capacity in ecosystem service provision with lower tree density. In future urban greening programs, more trees could be planted in attached green spaces and square green spaces to increase the total ecosystem service provision. The ecosystem services of public parks were quantified and acquired, indicating that public parks have the greatest ecosystem service provision capability for the city. Meanwhile, public parks that provide habitats for many kinds of animals, and recreation spaces for multiple activities to the general public should not be neglected. There has been huge investment every year in public parks management and maintenance. The trees in public parks are growing well under continuous and stable investment support, which further increases ecosystem service provision [73]. Meanwhile, strict regulations should be established to protect current public parks. In fact, the Department of Green Space Management in Luohe has released a series of rules and regulations, such as the Ecological Protection Redline Program [74] intended to permanently protect the public parks and leave them to future generations. 


\subsubsection{Air Pollution Removal of Urban Green Spaces}

As this study investigated the four main types of urban green spaces, air pollution removal by the whole green spaces across the city of Luohe was quantified. The air pollution removal capacities of urban green spaces were limited and could remove less than $10 \%$ of $\mathrm{PM}_{10}$ emissions in the city [3]. Trees in urban green spaces help to remove air pollution, while trees can also produce negative effects like pollen pollution, limiting pollution dispersion and increasing local pollution concentrations [75-77]. Hence, green space planning and management should be combined with other environmental protection plans and strategies (e.g., more efficient energy consumption technology). While climate adaption strategy continues to be involved in urban planning programs, urban green space ecosystem service provision has not been introduced and remains unconsidered due to a lack of scientific evidence. In many sustainable development projects focusing on the development of urban green space and green infrastructure, only the social and aesthetic factors were considered, which revealed that planners and policymakers need more information about the services provided by urban green spaces. This study quantified the air pollution removal capabilities of the four types of urban green spaces, which revealed a disparity in pollution removal capacities across the city. Acquiring the unequal distribution of green spaces could be used to improve urban sustainable planning within the city. Air pollution removal by urban green spaces in Luohe needs further research, considering the complex ecological process and functions in the future.

\subsubsection{Runoff Mitigation of Urban Green Space}

The results showed that urban green space is indeed effective in reducing flooding and various types of urban green spaces had different runoff avoiding capacities in Luohe. For example, each ha of public parks could avoid more than $51 \mathrm{~m}^{3}$ of rainfall runoff per year, which is the highest of the four types of green spaces. However, urban flooding became more and more serious with the acceleration of urbanization in Luohe, which was relatively common in China [78]. Urban green spaces cannot eliminate urban flooding, but can undoubtedly mitigate flooding damage by the interception effect. Urban green spaces are a key green infrastructure and, by combining with gray infrastructure, can improve flood mitigation effects. Urban green spaces are considered an effective component of stormwater management infrastructure and many cities are now considering urban green spaces as an important element for the effective implementation of sponge cities [79] or stormwater management strategies [80]. Meanwhile, urban green spaces could be a very cost-effective way to decrease the need for expensive gray infrastructure, such as retention tanks and sewer systems [81]. However, urban green spaces have very limited runoff avoiding capacity, indicating that the combined development of green and gray infrastructure would be more effective and practical for flooding mitigation [82,83]. The runoff avoiding performance of various types of urban green spaces was acquired. Apart from public parks, the other three types of green spaces had great potential to increase their runoff avoiding capacities via increasing tree density, replacing tree species with high leaf area index, and infiltration by improving the soil.

\subsection{Reliability and Limitations}

The i-Tree model is a publicly accessible toolset and technical support is available through email from the support team. By performing consistent, peer-reviewed procedures and on-site field survey data, the vegetation structure and ecosystem services of urban forests could be assessed and quantified by the i-Tree Eco model [25]. However, urban green spaces are complicated and normally it is difficult to assess the associated vegetation structure and to further estimate and quantify their ecosystem services. The i-Tree model is based on a sampling method within an entire study area and could provide a much more scientific and reasonable estimation of the entire population and ecosystem service provision of different sizes or species of trees [84]. More accurate locally collected field data would also lead to more reliable and precise eco-function estimation [25]. Derkzen et al. noted that 
one shortcoming of i-Tree Eco is that it does not discriminate between various types of urban green spaces [17]. Using super-high-resolution UAV images, our modified-sample-plot-creation approach showed how starting a proper stratification project to create stratified sample plots enabled i-Tree Eco to compare the ecosystem service provision of various types of urban green spaces. Our modified methodology enabled the mapping of the spatial distribution and ecosystem service provision of urban green spaces at a city scale, which can be adapted to other cities to explore ecosystem service provision by urban green spaces, further assisting municipal planning.

However, this study has some limitations. The precision of the ecosystem services depends on the number of samples and plot size. Normally, 200 random samples will produce a $12 \%$ standard error for the entire study area [49]. Therefore, more sample plots lead to a more precise estimation. Due to the available resources and limited funding support, 120 random sample plots were created within four types of urban green space in this study. Unlike other studies, where many plots were located in buildings, roads, etc., resulting in limited valid tree information, almost all the sample plots in this study were valid and a substantial amount of vegetation information was obtained. More sample plots would provide a more precise assessment of ecosystem service provision, while the time and cost of the field survey would increase [49]. A tradeoff decision should be made to find a proper balance between precision and cost. The assessment of vegetation structure and ecosystem services of urban green spaces had good consistency with ground-based estimations in other studies $[52,85,86]$. One more limitation is that only one year of meteorological and air quality data was used in this study; continuous long-term data would bring more detailed information about the ecosystem service provision. The i-Tree Eco model also calculates air pollution removal based on an average deposition velocity estimated from tree coverage area, leaf area index, and hourly local air pollution data. For individual tree contributions, the total pollutant removal is prorated to a single tree based on its proportion of the total leaf area. It should be noted that the different pollutant removal capabilities of various tree species are not considered and only the tree leaf area attribute is taken into consideration in the model. Further studies should be completed to fill the identified gaps.

\section{Conclusions}

Urban green spaces represent a fundamental component of urban ecosystems. Different types of urban green spaces with various vegetation communities and functions result in different ecosystem services. The purpose of this study was to reveal how various types of urban green space perform in ecosystem service and value provision in Luohe, exploring how to increase and maximize ecosystem services. The assessment and estimation of the vegetation structure and ecosystem services of urban green space provide a sound basis for ecosystem productivity of current urban green space in Luohe. As urban green spaces are growing and changing all the time, it is critical to acknowledge the spatial pattern and variation of urban green space ecosystem service provision. The efficiency of diverse types of urban green spaces in the provision of various ecosystem services could be used by urban planners or managers to set specific planning goals in the future. For green space projects where the implementation and maintenance costs are known, i-Tree Eco could be used to conduct a cost-benefit analysis, which would be helpful when planning urban green space. This study utilized an innovative method to collect field data to acknowledge the ecological values easily and reach a fuller understanding of various roles and functions of diverse types of urban green space. The i-Tree Eco model, as a free valuable tool to assess the ecosystem services of urban forests, has great potential to be used in relative research and other urban contexts. The results gained in this study can help urban planners, policymakers, and landscape architects to provide more rational planning or optimum proportions of various types of urban green space and maximize the ecosystem benefits as a key part of urban green infrastructure to support ecosystem balance.

Author Contributions: Conceptualization, P.S., G.T. and A.M.; methodology, P.S. and G.K.; software, P.S.; formal analysis, P.S.; investigation, P.S., G.T., R.H.; resources, G.T.; writing-original draft preparation, P.S.; writing-review and editing, P.S., G.K. and A.M.; visualization, R.H.; supervision, G.T., A.M.; funding acquisition, 
G.T., G.K. All the authors revised the manuscript. All authors have read and agreed to the published version of the manuscript.

Funding: This research was funded by Urban-Rural Green Space Resources Control and Landscape Ecological Design Disciplinary Innovation and Talents Introduction Centre Program (GXJD006), Education Department of Henan Province Program (18B220003) and Hanyang University (HY-201900000003487). And the APC was funded by Investigation and Database Construction of Green Spaces in Luohe Project (20161210).

Acknowledgments: We thank Lingyu Chen, Xinkai Niu, Kairui Xu and Hua Wang for helping us to collect the data in 2018; and appreciate Al Zelaya from Davey Tree Expert Company for continuous technical support to run i-Tree model.

Conflicts of Interest: The authors declare no conflict of interest.

\section{References}

1. Young, R.F. Managing municipal green space for ecosystem services. Urban For. Urban Green. 2010, 9, 313-321. [CrossRef]

2. Tzoulas, K.; Korpela, K.; Venn, S.; Yli-Pelkonen, V.; Kazmierczak, A.; Niemela, J.; James, P. Promoting ecosystem and human health in urban areas using Green Infrastructure: A literature review. Landsc. Urban Plan. 2007, 81, 167-178. [CrossRef]

3. Selmi, W.; Weber, C.; Rivière, E.; Blond, N.; Mehdi, L.; Nowak, D. Air pollution removal by trees in public green spaces in Strasbourg city, France. Urban For. Urban Green. 2016, 17, 192-201. [CrossRef]

4. Nowak, D.J.; Hirabayashi, S.; Doyle, M.; McGovern, M.; Pasher, J. Air pollution removal by urban forests in Canada and its effect on air quality and human health. Urban For. Urban Green. 2018, 29, 40-48. [CrossRef]

5. Jim, C.Y. Green-space preservation and allocation for sustainable greening of compact cities. Cities 2004, 21, 311-320. [CrossRef]

6. Buyadi, S.N.A.; Mohd, W.M.N.W.; Misni, A. Green spaces growth impact on the urban microclimate. Procedia-Soc. Behav. Sci. 2013, 105, 547-557. [CrossRef]

7. Xue, F.; Gou, Z.H.; Lau, S.S.Y. Green open space in high-dense Asian cities: Site configurations, microclimates and users' perceptions. Sustain. Cities Soc. 2017, 34, 114-125. [CrossRef]

8. Park, J.; Kim, J.H.; Lee, D.K.; Park, C.Y.; Jeong, S.G. The influence of small green space type and structure at the street level on urban heat island mitigation. Urban For. Urban Green. 2017, 21, 203-212. [CrossRef]

9. Aronson, M.F.J.; Lepczyk, C.A.; Evans, K.L.; Goddard, M.A.; Lerman, S.B.; MacIvor, J.S.; Nilon, C.H.; Vargo, T. Biodiversity in the city: Key challenges for urban green space management. Front. Ecol. Environ. 2017, 15, 189-196. [CrossRef]

10. Fuller, R.A.; Irvine, K.N.; Devine-Wright, P.; Warren, P.H.; Gaston, K.J. Psychological benefits of greenspace increase with biodiversity. Biol. Lett. 2007, 3, 390-394. [CrossRef]

11. Zhou, X.; Parves Rana, M. Social benefits of urban green space: A conceptual framework of valuation and accessibility measurements. Manag. Environ. Qual. Int. J. 2012, 23, 173-189. [CrossRef]

12. Fam, D.; Mosley, E.; Lopes, A.; Mathieson, L.; Morison, J.; Connellan, G. Irrigation of Urban Green Spaces: A Review of the Environmental, Social and Economic Benefits; CRC for Irrigation Futures Technical Report; Cooperative Research Centre for Irrigation Futures: Darling Heights, Australia, 2008.

13. Barbosa, O.; Tratalos, J.A.; Armsworth, P.R.; Davies, R.G.; Fuller, R.A.; Johnson, P.; Gaston, K.J. Who benefits from access to green space? A case study from Sheffield, UK. Landsc. Urban Plan. 2007, 83, 187-195. [CrossRef]

14. Li, F.; Wang, R. Evaluation, planning and prediction of ecosystem services of urban green space: A case study of Yangzhou City. Acta Ecol. Sin. 2003, 23, 1929-1936.

15. McPhearson, T.; Kremer, P.; Hamstead, Z.A. Mapping ecosystem services in New York City: Applying a social-ecological approach in urban vacant land. Ecosyst. Serv. 2013, 5, E11-E26. [CrossRef]

16. Kabisch, N. Ecosystem service implementation and governance challenges in urban green space planning-The case of Berlin, Germany. Land Use Policy 2015, 42, 557-567. [CrossRef]

17. Derkzen, M.L.; van Teeffelen, A.J.A.; Verburg, P.H. REVIEW Quantifying urban ecosystem services based on high-resolution data of urban green space: An assessment for Rotterdam, The Netherlands. J. Appl. Ecol. 2015, 52, 1020-1032. [CrossRef]

18. Kim, G.; Miller, P.A.; Nowak, D.J. Assessing urban vacant land ecosystem services: Urban vacant land as green infrastructure in the City of Roanoke, Virginia. Urban For. Urban Green. 2015, 14, 519-526. [CrossRef] 
19. Arnold, J.; Kleemann, J.; Furst, C. A Differentiated Spatial Assessment of Urban Ecosystem Services Based on Land Use Data in Halle, Germany. Land 2018, 7, 101. [CrossRef]

20. Kopecka, M.; Szatmari, D.; Rosina, K. Analysis of Urban Green Spaces Based on Sentinel-2A: Case Studies from Slovakia. Land 2017, 6, 25. [CrossRef]

21. Cilliers, S.; Cilliers, J.; Lubbe, R.; Siebert, S. Ecosystem services of urban green spaces in African countries-perspectives and challenges. Urban Ecosyst. 2013, 16, 681-702. [CrossRef]

22. Haase, D.; Larondelle, N.; Andersson, E.; Artmann, M.; Borgstrom, S.; Breuste, J.; Gomez-Baggethun, E.; Gren, A.; Hamstead, Z.; Hansen, R.; et al. A quantitative review of urban ecosystem service assessments: Concepts, models, and implementation. Ambio 2014, 43, 413-433. [CrossRef] [PubMed]

23. Haaland, C.; van Den Bosch, C.K. Challenges and strategies for urban green-space planning in cities undergoing densification: A review. Urban For. Urban Green. 2015, 14, 760-771. [CrossRef]

24. Oberndorfer, E.; Lundholm, J.; Bass, B.; Coffman, R.R.; Doshi, H.; Dunnett, N.; Gaffin, S.; Kohler, M.; Liu, K.K.Y.; Rowe, B. Green roofs as urban ecosystems: Ecological structures, functions, and services. Bioscience 2007, 57, 823-833. [CrossRef]

25. Nowak, D.J.; Crane, D.E.; Stevens, J.C.; Hoehn, R.E.; Walton, J.T.; Bond, J. A ground-based method of assessing urban forest structure and ecosystem services. Aboricult. Urban For. 2008, 34, 347-358.

26. Chen, W.Y.; Jim, C.Y. Assessment and Valuation of the Ecosystem Services Provided by Urban Forests. In Ecology, Planning, and Management of Urban Forests; Springer: New York, NY, USA, 2008; pp. 53-83.

27. Jim, C.Y.; Chen, W.Y. Ecosystem services and valuation of urban forests in China. Cities 2009, 26, 187-194. [CrossRef]

28. Robinson, S.L.; Lundholm, J.T. Ecosystem services provided by urban spontaneous vegetation. Urban Ecosyst. 2012, 15, 545-557. [CrossRef]

29. Lehmann, I.; Mathey, J.; Rossler, S.; Brauer, A.; Goldberg, V. Urban vegetation structure types as a methodological approach for identifying ecosystem services-Application to the analysis of micro-climatic effects. Ecol. Indic. 2014, 42, 58-72. [CrossRef]

30. Czembrowski, P.; Kronenberg, J. Hedonic pricing and different urban green space types and sizes: Insights into the discussion on valuing ecosystem services. Landsc. Urban Plan. 2016, 146, 11-19. [CrossRef]

31. Tratalos, J.; Fuller, R.A.; Warren, P.H.; Davies, R.G.; Gaston, K.J. Urban form, biodiversity potential and ecosystem services. Landsc. Urban Plan. 2007, 83, 308-317. [CrossRef]

32. Holt, A.R.; Mears, M.; Maltby, L.; Warren, P. Understanding spatial patterns in the production of multiple urban ecosystem services. Ecosyst. Serv. 2015, 16, 33-46. [CrossRef]

33. Andersson, E.; Barthel, S.; Ahrne, K. Measuring social-ecological dynamics behind the generation of ecosystem services. Ecol. Appl. 2007, 17, 1267-1278. [CrossRef] [PubMed]

34. Grove, J.M.; Troy, A.R.; O’Neil-Dunne, J.P.M.; Burch, W.R.; Cadenasso, M.L.; Pickett, S.T.A. Characterization of households and its implications for the vegetation of urban ecosystems. Ecosystems 2006, 9, 578-597. [CrossRef]

35. Muller, N.; Werner, P.; Kelcey, J.G. Urban Biodiversity and Design; John Wiley \& Sons: Hoboken, NJ, USA, 2010.

36. Threlfall, C.G.; Ossola, A.; Hahs, A.K.; Williams, N.S.G.; Wilson, L.; Livesley, S.J. Variation in Vegetation Structure and Composition across Urban Green Space Types. Front. Ecol. Evol. 2016, 4, 66. [CrossRef]

37. Buyadi, S.N.A.; Mohd, W.; Misni, A. Quantifying Green Space Cooling Effects on the Urban Microclimate Using Remote Sensing and GIS Techniques. In Proceedings of the XXV International Federation of Surveyors, Kuala Lumpur, Malaysia, 16-21 June 2014; pp. 1-16.

38. O’Malley, C.; Piroozfar, P.; Farr, E.R.P.; Pomponi, F. Urban Heat Island (UHI) mitigating strategies: A case-based comparative analysis. Sustain. Cities Soc. 2015, 19, 222-235. [CrossRef]

39. Wu, Z.J.; Zhang, Y.X. Spatial Variation of Urban Thermal Environment and Its Relation to Green Space Patterns: Implication to Sustainable Landscape Planning. Sustainability 2018, 10, 2249. [CrossRef]

40. Nowak, D.J.; Dwyer, J.F. Understanding the Benefits and Costs of Urban Forest Ecosystems. In Urban and Community Forestry in the Northeast; Springer: Boston, MA, USA, 2007; pp. 25-46.

41. Yapp, G.; Walker, J.; Thackway, R. Linking vegetation type and condition to ecosystem goods and services. Ecol. Complex 2010, 7, 292-301. [CrossRef]

42. Petter, M.; Mooney, S.; Maynard, S.M.; Davidson, A.; Cox, M.; Horosak, I. A Methodology to Map Ecosystem Functions to Support Ecosystem Services Assessments. Ecol. Soc. 2013, 18, 31. [CrossRef] 
43. Werling, B.P.; Dickson, T.L.; Isaacs, R.; Gaines, H.; Gratton, C.; Gross, K.L.; Liere, H.; Malmstrom, C.M.; Meehan, T.D.; Ruan, L.; et al. Perennial grasslands enhance biodiversity and multiple ecosystem services in bioenergy landscapes. Proc. Natl. Acad. Sci. USA 2014, 111, 1652-1657. [CrossRef]

44. Wang, H.-F.; Qureshi, S.; Knapp, S.; Friedman, C.R.; Hubacek, K. A basic assessment of residential plant diversity and its ecosystem services and disservices in Beijing, China. Appl. Geogr. 2015, 64, 121-131. [CrossRef]

45. Ziter, C. The biodiversity-ecosystem service relationship in urban areas: A quantitative review. Oikos 2016, 125, 761-768. [CrossRef]

46. Richards, D.R.; Edwards, P.J. Quantifying street tree regulating ecosystem services using Google Street View. Ecol. Indic. 2017, 77, 31-40. [CrossRef]

47. i-Tree. i-Tree Eco User's Manual_V6.0. Available online: https://www.itreetools.org/support/resourcesoverview/i-tree-manuals-workbooks (accessed on 8 August 2018).

48. Husson, E.; Ecke, F.; Reese, H.J.R.S. Comparison of maual mapping and automated object-based image analysis of non-submerged aquatic vegetation from very-high-resolution UAS images. Remote Sens. 2016, 8 , 724. [CrossRef]

49. Nowak, D.J.; Walton, J.T.; Stevens, J.C.; Crane, D.E.; Hoehn, R.E. Effect of plot and sample size on timing and precision of urban forest assessments. Aboricult. Urban For. 2008, 34, 386-390.

50. Baró, F.; Haase, D.; Gómez-Baggethun, E.; Frantzeskaki, N. Mismatches between ecosystem services supply and demand in urban areas: A quantitative assessment in five European cities. Ecol. Indic. 2015, 55, 146-158. [CrossRef]

51. Intasen, M.; Hauer, R.J.; Werner, L.P.; Larsen, E. Urban forest assessment in Bangkok, Thailand. J. Sustain. For. 2017, 36, 148-163. [CrossRef]

52. Graca, M.; Alves, P.; Goncalves, J.; Nowak, D.J.; Hoehn, R.; Farinha-Marques, P.; Cunha, M. Assessing how green space types affect ecosystem services delivery in Porto, Portugal. Landsc. Urban Plan. 2018, 170, 195-208. [CrossRef]

53. Kim, G.; Miller, P.A.; Nowak, D.J. Urban vacant land typology: A tool for managing urban vacant land. Sustain. Cities Soc. 2018, 36, 144-156. [CrossRef]

54. Gormanson, D.D.; Pugh, S.A.; Barnett, C.J.; Miles, P.D.; Morin, R.S.; Sowers, P.A.; Westfall, J.A. Statistics and Quality Assurance for the Northern Research Station Forest Inventory and Analysis Program; Gen. Tech. Rep. NRS-178; US Department of Agriculture, Forest Service, Northern Research Station: Newtown Square, PA, USA, 2018. [CrossRef]

55. Luz de la Maza, C.; Hernández, J.; Bown, H.; Rodríguez, M.; Escobedo, F. Vegetation diversity in the Santiago de Chile urban ecosystem. Arboric. J. 2002, 26, 347-357. [CrossRef]

56. Fenger, J. Urban air quality. Atmos. Environ. 1999, 33, 4877-4900. [CrossRef]

57. Nowak, D.J.; Crane, D.E.; Stevens, J.C. Air pollution removal by urban trees and shrubs in the United States. Urban For. Urban Green. 2006, 4, 115-123. [CrossRef]

58. Jim, C.Y.; Chen, W.Y. Assessing the ecosystem service of air pollutant removal by urban trees in Guangzhou (China). J. Environ. Manag. 2008, 88, 665-676. [CrossRef] [PubMed]

59. Nowak, D.J.; Hirabayashi, S.; Bodine, A.; Greenfield, E.J. Tree and forest effects on air quality and human health in the United States. Environ. Pollut. 2014, 193, 119-129. [CrossRef]

60. Grote, R.; Samson, R.; Alonso, R.; Amorim, J.H.; Cariñanos, P.; Churkina, G.; Fares, S.; Thiec, D.L.; Niinemets, Ü.; Mikkelsen, T.N. Functional traits of urban trees: Air pollution mitigation potential. Front. Ecol. Environ. 2016, 14, 543-550. [CrossRef]

61. Nowak, D.J. The Effects of Urban Trees on Air Quality; USDA Forest Service: Syracuse, NY, USA, 2002; pp. 1-4.

62. Hirabayashi, S.; Kroll, C.N.; Nowak, D.J. Development of a distributed air pollutant dry deposition modeling framework. Environ. Pollut. 2012, 171, 9-17. [CrossRef] [PubMed]

63. Kubal, C.; Haase, D.; Meyer, V.; Scheuer, S.J.N. Integrated urban flood risk assessment-adapting a multicriteria approach to a city. Nat. Hazards Earth Syst. Sci. 2009, 9, 1881-1895. [CrossRef]

64. Yin, J.; Ye, M.; Yin, Z. A review of advances in urban flood risk analysis over China. Stoch. Environ. Res. Risk 2015, 29, 1063-1070. [CrossRef]

65. Sauer, E.P.; VandeWalle, J.L.; Bootsma, M.J.; McLellan, S.L. Detection of the human specific Bacteroides genetic marker provides evidence of widespread sewage contamination of stormwater in the urban environment. Water Res. 2011, 45, 4081-4091. [CrossRef] 
66. Xiao, Q.; McPherson, E.G.; Ustin, S.L.; Grismer, M.E. A new approach to modeling tree rainfall interception. J. Geophys. Res. Atmos. 2000, 105, 29173-29188. [CrossRef]

67. Wang, J.; Endreny, T.A.; Nowak, D.J. Mechanistic simulation of tree effects in an urban water balance model 1. J. Am. Water Resour. 2008, 44, 75-85. [CrossRef]

68. Armson, D.; Stringer, P.; Ennos, A.J.U.F.; Greening, U. The effect of street trees and amenity grass on urban surface water runoff in Manchester, UK. Urban For. Urban Green. 2013, 12, 282-286. [CrossRef]

69. Zhang, B.; Li, N.; Wang, S. Effect of urban green space changes on the role of rainwater runoff reduction in Beijing, China. Landsc. Urban Plan. 2015, 140, 8-16. [CrossRef]

70. Peterson, G.; Allen, C.R.; Holling, C.S. Ecological resilience, biodiversity, and scale. Ecosystems 1998, 1, 6-18. [CrossRef]

71. Duffy, J.E. Why biodiversity is important to the functioning of real-world ecosystems. Front. Ecol. Environ. 2009, 7, 437-444. [CrossRef]

72. Yang, L.; Wu, Y.; Zhou, X. Study on Attached Green Space Planning and Management in Office and Residential Areas in Old City Districts-A Case Study of Changji in Xinjiang. Chin. Landsc. Archit. 2013, 3, 55-58.

73. Shu, J.; Zhang, Y.; Yin, J.; Song, Q.; Cong, R.; Yu, W. Research on Urban Public Park Maintaince and Management Cost Standard-Case in Beijing. 2011 Beijing Urban Greening and Biodiversity Protection; Scientific and Technical Documentation Press: Beijing, China, 2011.

74. Wan, J.; Yu, L.; Zhang, P.; Wang, C.; Zhang, N. Method and Application of Urban Ecological Protection Redline. Environ. Prot. Sci. 2015, 5, 6-11.

75. Wania, A.; Bruse, M.; Blond, N.; Weber, C. Analysing the influence of different street vegetation on traffic-induced particle dispersion using microscale simulations. J. Environ. Manag. 2012, 94, 91-101. [CrossRef]

76. Salmond, J.A.; Williams, D.E.; Laing, G.; Kingham, S.; Dirks, K.; Longley, I.; Henshaw, G.S. The influence of vegetation on the horizontal and vertical distribution of pollutants in a street canyon. Sci. Total Environ. 2013, 443, 287-298. [CrossRef]

77. Klimas, C.; Williams, A.; Hoff, M.; Lawrence, B.; Thompson, J.; Montgomery, J. Valuing Ecosystem Services and Disservices across Heterogeneous Green Spaces. Sustainability 2016, 8, 853. [CrossRef]

78. Chen, Y.; Zhou, H.; Zhang, H.; Du, G.; Zhou, J. Urban flood risk warning under rapid urbanization. Environ. Res. 2015, 139, 3-10. [CrossRef]

79. Li, H.; Ding, L.; Ren, M.; Li, C.; Wang, H. Sponge City Construction in China: A Survey of the Challenges and Opportunities. Water 2017, 9, 594. [CrossRef]

80. Jayasooriya, V.M.; Ng, A.W.M. Tools for Modeling of Stormwater Management and Economics of Green Infrastructure Practices: A Review. Water Air Soil Pollut. 2014, 225, 2055. [CrossRef]

81. Berland, A.; Shiflett, S.A.; Shuster, W.D.; Garmestani, A.S.; Goddard, H.C.; Herrmann, D.L.; Hopton, M.E. The role of trees in urban stormwater management. Landsc. Urban Plan. 2017, 162, 167-177. [CrossRef] [PubMed]

82. Mell, I.C.; Henneberry, J.; Hehl-Lange, S.; Keskin, B. To green or not to green: Establishing the economic value of green infrastructure investments in the Wicker, Sheffield. Urban For. Urban Green. 2016, 18, 257-267. [CrossRef]

83. Xie, J.; Chen, H.; Liao, Z.; Gu, X.; Zhu, D.; Zhang, J. An integrated assessment of urban flooding mitigation strategies for robust decision making. Environ. Model. Softw. 2017, 95, 143-155. [CrossRef]

84. Nowak, D.J.; Crane, D.E.; Stevens, J.C.; Hoehn, R.E. The Urban Forest Effects (UFORE) Model: Field Data Collection Manual; US Department of Agriculture Forest Service, Northeastern Research Station: Syracuse, NY, USA, 2003; pp. 4-11.

85. Nowak, D.J.; Greenfield, E.J.; Hoehn, R.E.; Lapoint, E. Carbon storage and sequestration by trees in urban and community areas of the United States. Environ. Pollut. 2013, 178, 229-236. [CrossRef]

86. Bodnaruk, E.W.; Kroll, C.N.; Yang, Y.; Hirabayashi, S.; Nowak, D.J.; Endreny, T.A. Where to plant urban trees? A spatially explicit methodology to explore ecosystem service tradeoffs. Landsc. Urban Plan. 2017, 157, 457-467. [CrossRef]

(C) 2020 by the authors. Licensee MDPI, Basel, Switzerland. This article is an open access article distributed under the terms and conditions of the Creative Commons Attribution (CC BY) license (http://creativecommons.org/licenses/by/4.0/). 